\title{
Sistem Pakar Diagnosis Kerusakan Jaringan Local Area Network (LAN) Menggunakan Metode Forward Chaining
}

\author{
Robby Rizky ${ }^{1}$, Andrianto Heri Wibowo ${ }^{2}$, Zaenal Hakim ${ }^{3}$, Lili Sujai ${ }^{4}$ \\ 1,2,3,4 Jurusan Manajemen Informatika Universitas Mathla'ul Anwar Banten Labuan, Cikaliung, Saketi, Pandeglang - \\ Banten 42273 Telp.(0253) 401555 \\ ${ }^{1}$ robby.rizky@unmabanten.ac.id \\ 2 andrianto@unmabanten.ac.id \\ ${ }^{3}$ hakimzaenal@unmabanten.ac.id \\ ${ }^{4}$ lilisujai@unma banten.ac.id
}

Intisari - Sistem pakar merupakan teknologi berbasis pengetahuan, fakta dan penalaran yang dapat digunakan untuk menyelesaikan berbagai masalah dalam berbagai disiplin ilmu diantaranya adalah masalah diagnosa. Platform pemrograman yang akan digunakan dalam mengimplementasikan sistem pakar kerusakan jaringan LAN ini adalah java yang mana lebih sederhana dalam penggunaan metode inferensi Forward Chaining dengan model dept first search. Sistem pakar ini dalam penggunaannya dapat dijalankan dengan cara menjawab setiap pertanyaan dengan ya atau tidak dan akan menghasilkan suatu prediksi kerusakan atau gangguan yang sedang dialami. Keluaran dari sistem ini berupa Jenis kerusakan atau gangguan, serta solusi perbaikan berdasarkan sumber data dari ahli yang disebut pakar. Sistem pakar untuk mendiagnosa kerusakan jaringan LAN, sehingga dapat membantu User dan Pakar dalam mendiagnosi kerusakan atau berupa gangguan pada jaringan LAN dan mengenali gejala, jenis kerusakan dan solusi / diagnosa awal. Untuk memudahkan User berkonsultasi kepada pakar jaringan LAN ketika pa kar yang bersangkutan tidak ada, dikarnakan pakar jaringan LAN pada. PT.Telkom STO Menes masih sangat terbatas, sedangkan pengguna jaringan LAN semakin tahun semakin meningkat. Data kerusakan dan gejala kerusakan tidak tersimpan secara komputerisasi dan pelayanan yang memakan waktu mengakibatkan informasi konsultasi awal tidak berjalan maksimal. Maka penulis tertarik melakukan penelitian sistem pakar dengan judul Sistem Pakar Diagnosis Kerusakan Jaringan Local Area Network (LAN).

Kata kunci - sistem pakar,forward chaining,diagnosis kerusakan jaringan LAN

Abstract - Expert system is a technology based on knowledge, facts and reasoning that can be used to solve various problems in various disciplines including diagnostic problems. The programming platform that will be used in implementing this expert system for LAN network damage is java which is simpler in using the Forward Chaining inference method with the first search dept model. This expert system in its use can be run by answering each question yes or no and will produce a prediction of damage or disturbance that is being experienced. The output of this system is a type of damage or disturbance, as well as repair solutions based on data sources from experts called experts. Expert system to diagnose LAN network damage, so that it can help Users and Experts in diagnosing damage or in the form of disruption on the LAN network and recognize symptoms, types of damage and initial solutions / diagnoses. To make it easier for users to consult a LAN network expert when the relevant expert is not present, the LAN network expert is invited. PT.Telkom STO Menes is still very limited, while LAN network users are increasing every year. Damage data and damage symptoms are not computerized and time-consuming services result in initial consultation information not running optimally. So the authors are interested in conducting expert system research with the title Expert System Diagnosis of Local Area Network (LAN) Network Damage.

Keywords - expert system, forward chaining, diagnosis of LAN network damage

\section{PENDAhUluan}

Pengetahuan merupakan salah satu kebutuhan penting dalam kehidupan manusia pengetahuan yang luas memberikan solusi pemecahan suatu masalah yang ada dan menyelasaikannya dengan berfikir secara kritis, pengetahuan biasanya hanya dimiliki oleh seorang pakar. Pakar merupakan seseorang yang memiliki keahlian atau pengetahuan yang luas dalam bidang tertentu.
Maka untuk menerapkan dan menyebarkan pengetahuan seorang pakar diperlukan sebuah sistem yang disebut sistem pakar (Expert System). Sistem pakar merupakan program komputer yang dirancang untuk meniru pengetahuan seorang pakar. Sistem pakar pada umumnya merupakan sistem yang mengadopsi pengetahuan manusia ke komputer, agar komputer dapat menyelesaikan masalah seperti yang biasa dilakukan oleh para ahli. Dengan kata lain, sistem pakar 
adalah sistem yang didesain dan diimplementasikan dengan bantuan bahasa pemprograman tertentu untuk dapat menyelesaikan masalah seperti yang dilakukan para ahli. Sistem pakar juga dapat melakukan pengambilan kesimpulan dalam waktu yang konsisten, bahkan dapat menghasilkan kesimpulan lebih cepat daripada seorang pakar.

Diera globalisasi ini internet menjadi pokok kebutuhan masyarakat karna perkembangan teknologi yang semakin tahun semakin meningkat. Hampir semua bidang baik teknologi, pendidikan, serta persaingan dunia bisnis menggunakan internet. Penggunaan internet dapat dinikmati oleh semua kalangan baik muda atau tua. Untuk menghubungkan suatu komputer ke jaringan dapat menggunakan media kabel (wired) dan nirkabel (wireless). Ada beberapa jenis jaringan komputer dilihat dari kebutuhan dan geografisnya, antara lain jaringan LAN (Local Area Network), MAN (Metropolitan Area Network), WAN (Wide Area Network). LAN adalah jaringan komputer dalam lingkup kecil dan berada dalam satu ruangan. Jaringan MAN hampir sama dengan jaringan LAN tetapi dengan lingkup geografis yang lebih luas, misalnya antar sebuah gedung. WAN adalah jaringan komputer antar sebuah kota.

Dari beberapa penjelasan tersebut dapat disimpulkan pengimplementasian jaringan komputer sangat penting dan banyak diterpakan diberbagai aspek. Yaitu pada dunia pendidikan baik itu lingkungan sekolah maupun kampus dan dunia bisnis seperti warnet yang memerlukan koneksi internet Local Area Network (LAN) bahkan tempat umum dan lain sebagainya dan pada sistem pakar ini peneliti menggunakan metode Forward Chaining untuk mendiagnosis kerusakan jaringan LAN yang dimana rule nya mulai dari pendiagnosaan gejala-gejala setelah itu jenis kerusakan dan terakhir solusi dari kerusakan jaringan LAN tersebut.

Gangguan kerusakan pada LAN seringkali merepotkan para pengguna jaringan internet karna kurang pengetahuan tentang kerusakan tersebut. Oleh sebab itu diperlukan suatu sistem yang dapat digunakan untuk menghimpun data pengetahuan para ahli jaringan LAN dan menyimpannya untuk jangka waktu yang panjang. Data-data berupa jenis kerusakan, gejala kerusakan, dan solusi pencegahan tersebut nantinya akan digunakan untuk menjawab pertanyaan yang menyangkut diagnosis hingga memberikan solusi perbaikannya dengan menggunakan alur penalaran yang disediakan, sehingga sistem pakar ini dapat digunakan untuk memberikan solusi dari masalah secara umum untuk membantu pakar dalam menyelesaikan permasalahan terkait kerusakan jaringan LAN. mendiagnosa kerusakan jaringan LAN, sehingga dapat membantu User dan Pakar dalam mendiagnosi kerusakan atau berupa gangguan pada jaringan LAN dan mengenali gejala, jenis kerusakan dan solusi / diagnosa awal. Untuk memudahkan User berkonsultasi kepada pakar jaringan LAN ketika pakar yang bersangkutan tidak ada, dikarnakan pakar jaringan LAN pada. PT.Telkom STO Menes masih sangat terbatas, sedangkan pengguna jaringan LAN semakin tahun semakin meningkat. Data kerusakan dan gejala kerusakan tidak tersimpan secara komputerisasi dan pelayanan yang memakan waktu mengakibatkan informasi konsultasi awal tidak berjalan maksimal. Maka penulis tertarik melakukan penelitian sistem pakar dengan judul Sistem Pakar Diagnosis Kerusakan Jaringan Local Area Network (LAN) Menggunakan Metode Forward Chaining.

\section{A. Perumusan Masalah}

Berdasarkan latar belakang yang telah diuraikan, maka dengan ini penulis merumuskan masalah yaitu sebagai berikut :

1) Bagaimana merancang sebuah aplikasi sistem pakar untuk mendiagnosis kerusakan jaringan Lokal Area Network (LAN) menggunakan metode Forward Chaining yang mudah dimengerti oleh User atau Pengguna.

2) Bagaimana merancang dan membangun aplikasi sistem pakar yang dapat 
mendiagnosis dan dapat memberikan informasi tentang kerusakan jaringan LAN, serta dapat memberikan solusi berdasarkan pengetahuan pakar .

\section{B. Pembatasan Masalah}

Pembatasan masalah pada penelitian ini dibuat untuk menghindari pembahasan yang terlalu meluas, maka pada penulisan penelitian ini akan dibahas mengenai :

1) Sistem pakar ini mendiagnosis kerusakan jaringan LAN.

2) Rancangan sistem pakar berbasis .

3) Metode yang digunakan pada sistem pakar ini adalah metode Forward Chaining.

4) Dalam Perancangan sistemnya menggunakan PHP dan Database My SQL.

5) Pada sistem pakar ini hanya mendiagnosis kerusakan atau gangguan kecil pada jaringan LAN.

Kerusakan jaringan LAN dapat berupa kerusakan fisik dan berupa gangguan pada perangkat.

\section{Tujuan Penelitian}

Berikut merupakan tujuan penulisan penelitian ini adalah sebagai berikut :

a. Merancang dan membuat sebuah sistem pakar berbasis web untuk memberikan informasi terkait kerusakan jaringan LAN serta dapat memberikan solusi secara cepat dan tepat.

b. Membuat sebuah sistem untuk membantu dan memberikan pemahaman atau pengetahuan terhadap user tentang kerusakan jaringan LAN.

\section{Metodologi Penelitian}

Metode yang dipakai dalam penelitian ini adalah metode penelitian deskriptif. Dimana metode ini merupakan salah satu metode yang menggambarkan secara akurat, faktual, dan sistematis mengenai informasi yang sesuai dengan fakta-fakta yang ditemui di lapangan.

\section{A. Metode Pengumpulan Data}

Sugiyono (2013:224), metode pengumpulan data merupakan langkah yang paling strategis dalam penelitian, karena tujuan utama dari penelitian adalah mendapatkan data.

Berikut metode pengumpulan data yang digunakan oleh penulis saat penelitian:

1. Metode Wawancara (Interview)

Teknik pengumpulan data yang penulis lakukakan yaitu dengan cara tanya jawab secara langsung kepada teknisi pada PT.Telkom STO Menes selaku pakar dengan kajian yang sudah disusun sehingga memperoleh data yang relevan untuk menunjang penelitian yang berkaitan dengan topik yang diambil, yakni tentang System Pakar Diagnosis Kerusakan Jaringan LAN menggunakan metode Forward Chaining.

2. Metode observasi (pengamatan langsung) Teknik lain yang penulis lakukan untuk pengumpulan data yaitu dengan cara melihat langsung jenis gangguan dan proses penganannya.

3. Metode kepustakaan

Teknik yang terakhir yakni dengan cara mempelajari, meneliti,serta menelaah berbagai literatur dari beragam sumber mulai dari buku-buku, jurnal ilmiah, situs internet, dan media-media lainnya yang berkaitan dengan penelitian yang dilakukan.

\section{HASIL DAN PEMBAHASAN}

Analisis sistem (system analysis) dapat didefinisikan sebagai penguraian dari suatu sistem informasi yang utuh ke dalam bagianbagian komponennya dengan maksud untuk mengidentifikasi dan mengevaluasi permasalahan-permasalahan, kesempatankesempatan, hambatan-hambatan yang terjadi dan kebutuhan-kebutuhan yang diharapkan sehingga dapat diusulkan perbaikanperbaikannya.

Sebagai analisis pada sistem yang sedang berjalan, akan dibahas bagaimana prosedur dan aliran dokumen yang sedang berjalan digambarkan dalam bentuk flow map, pengkodean dan analisis sistem non fungsional yang meliputi perangkat keras dan 
perangkat lunak yang digunakan, serta analisis user yang terlibat.

Adapun analisis sistem yang dibutuhkan oleh penulis antara lain:

Analisis input data yaitu sebuah sistem yang sedang berjalan untuk memasukan data atau input data, data yang di-inputkan adalah sebagai berikut:

\section{Input Data Admin}

2. Input Data User

3. Input Data Keruskan

4. Input Data Gejala

5. Input Data Solusi

\section{A. Perancangan Flow of System (FOS)}

Flow of system adalah alur data yang menggambarkan sistem terkomputerisasi yang sedang berjalan, adapun alur datanya sebagai berikut:

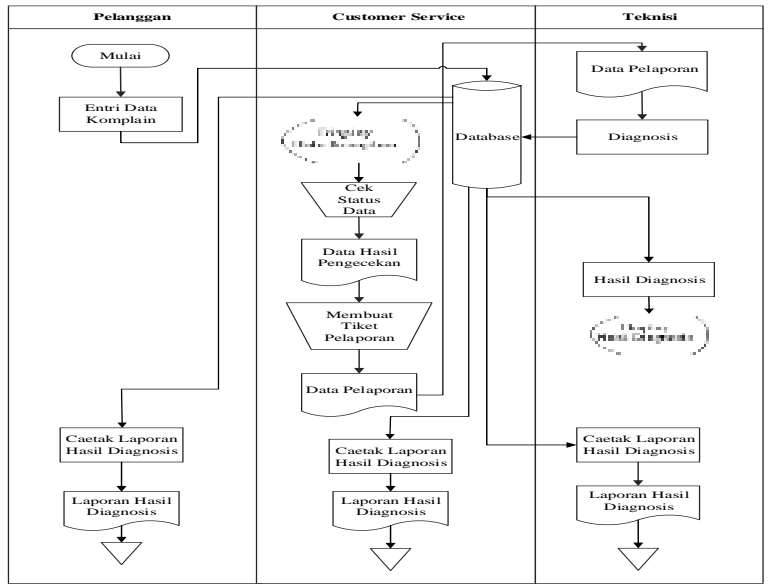

Gambar 1. Perancangan Flow System

B. Perancangan Diagram Konteks (Context Diagram) Diagram konteks ini dirancang dengan memperhatikan masukan yang dibutuhkan oleh sistem dan keluaran yang dihasilkan oleh sistem. Berikut adalah gambar dari diagram konteks diagnosis Kerusakan pada jarngan LAN.

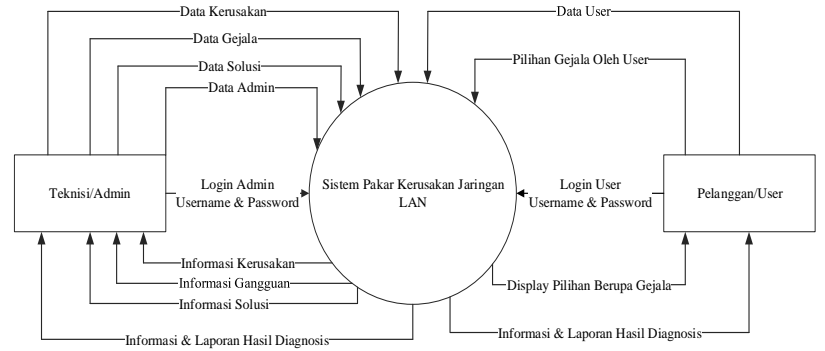

Gambar 2. Diagram Konteks
C. Perancangan Data Flow Diagram

Pada perancangan DFD level 0 ini membahas tentang penjabaran sistem yang akan dirancang berdasarkan rancangan pada konteks diagram Berikut adalah gambar DFD Diagnosis Kerusakan Jaringan LAN yang diusulkan.

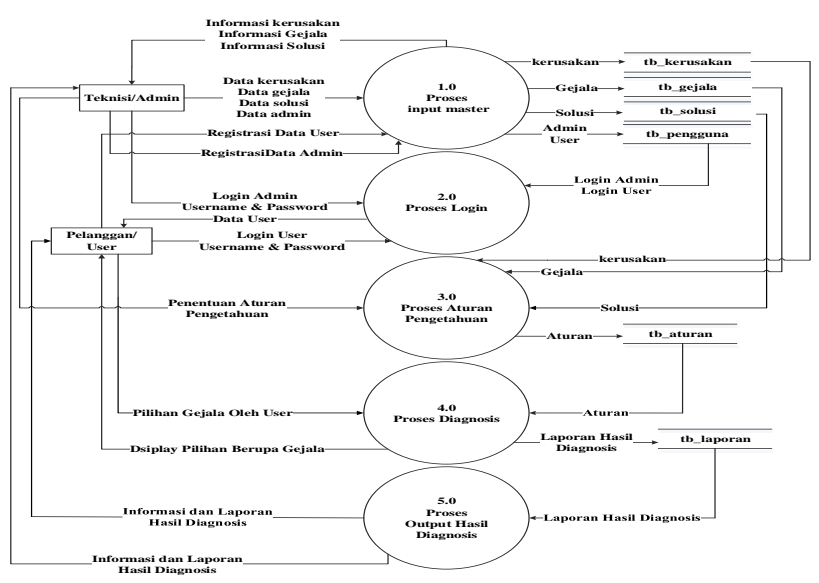

Gambar 3. DFD Level 0

D. Analisa menggunakan metode forward chaining.

Tabel 1. Pembentukan Aturan

\begin{tabular}{|c|c|c|}
\hline No & $\begin{array}{c}\text { Aturan Gejala } \\
\text { Kerusakan/Gangguan }\end{array}$ & Aturan Solusi \\
\hline 1. & $\begin{array}{l}\text { IF Nama Wifi } \\
\text { menghilangAND } \\
\text { Password berubah AND } \\
\text { Nama Wifi kembali ke } \\
\text { setingan Awal THEN } \\
\text { Router Default }\end{array}$ & $\begin{array}{l}\text { IFMenampilkan Nama wifi, } \\
\text { Masuk ke Menu Network, } \\
\text { WLAN, pilih menu SSID } \\
\text { Settings, Hilangkan Centang } \\
\text { Pada Kolom Hidde SSID. } \\
\text { AND Mengganti password wifi } \\
\text { indihome zte, Klik menu } \\
\text { Networkpilih WLAN lalu } \\
\text { Security, pada bagian kolom } \\
\text { WPA Prassphrase, ganti } \\
\text { password wifi indohome sesuai } \\
\text { dengan keinginan Anda } \\
\text { (minimal } 8 \text { maksimal } 63 \\
\text { karakter).ANDMengganti ID } \\
\text { Nama Wifi Indihome, Menu } \\
\text { Network, WLAN, pilih menu } \\
\text { SSID Settings dan pada bagian } \\
\text { kolom SSID Name ganti } \\
\text { dengan nama WIFI Indihome } \\
\text { yang anda } \\
\text { inginkan.THENRouter Default }\end{array}$ \\
\hline 2. & $\begin{array}{l}\text { IFHotspot tidak } \\
\text { menggunakan DHCP } \\
\text { atau IP secara otomatis } \\
\text { AND Loadig pagelambat } \\
\text { saat browsing AND } \\
\text { Terlalu banyak } \\
\text { PenggunaTHENInternet } \\
\text { Limited acces }\end{array}$ & $\begin{array}{l}\text { IF Mereset IP (TCP/IP): Masuk } \\
\text { ke cmd administrator pada cmd } \\
\text { ketik perintah netsh int ip reset } \\
c \text { : esetlog.txt lalu restart } \\
\text { laptop/pc. ANDlakukan } \\
\text { pembersihan pada cache pada } \\
\text { browser yang digunakan, } \\
\text { kurangi kegiatan download file } \\
\text { yang melebihi batas } A N D \\
\text { Hindari pengguna jaringan }\end{array}$ \\
\hline
\end{tabular}




\begin{tabular}{|c|c|c|}
\hline & & $\begin{array}{l}\text { yang melebihi batas, dan } \\
\text { lakukan secara berkala } \\
\text { penggantian password jaringan } \\
\text { yang } \\
\text { gunakanTHENInternet } \\
\text { acces }\end{array}$ \\
\hline 3. & $\begin{array}{l}\text { IF Indikator pada LAN } \\
\text { Card tidak menyalaAND } \\
\text { Indikator HUB/Swich } \\
\text { tidak menyala AND } \\
\text { Kabel tidak terpasang } \\
\text { dengan baik/rusak THEN } \\
\text { Network cable is } \\
\text { Unplugged }\end{array}$ & $\begin{array}{l}\text { IF Cek Lan Card jika status off } \\
\text { hidupkan terlebih dahulu, jika } \\
\text { Lan Card dalam keadaan } \\
\text { normal maka cek kabel yang } \\
\text { terhubung. AND Pastikan } \\
\text { kondisi kabel dalam keadaan } \\
\text { baik. AND Ganti kabel jika } \\
\text { tidak layak Pakai THEN } \\
\text { Network cable is Unplugged }\end{array}$ \\
\hline 4. & $\begin{array}{lr}\text { IF Simbol Wifi tanda } \\
\text { seru } & \text { kuningAND } \\
\text { Terdapat } I P \text { yang } & \text { sama } \\
\text { dibeberapa } & \\
\text { penggunaAND } & \\
\text { Menggunakan } & I P \\
\text { address yang } & \text { Statis } \\
\text { THEN IP } & \text { address } \\
\text { conflict } & \end{array}$ & $\begin{array}{l}\text { IFMasuk ke Control Panel } \\
\text { pada Laptop anda, Klik } \\
\text { Network and Sharing Center, } \\
\text { Selanjutnya anda klik Change } \\
\text { Adapter Settings. Setelah itu } \\
\text { anda pilih Wireless Network } \\
\text { Connection. Klik dua kali pada } \\
\text { tulisan Internet Protocol } \\
\text { Version } 4 \text { (TCP/IPV4).Disitu } \\
\text { anda akan melihat Detail } \\
\text { alamat IP anda. Lalu klik pada } \\
\text { tulisan Obtain an IP Address } \\
\text { Automatically terakhir klik } \\
\text { OK.ANDJalankan command } \\
\text { prompt (CMD) Klik Start dan } \\
\text { Cari CMD Ketik perintah } \\
\text { dibawah ini pada CMD Ketik } \\
\text { ipconfig/release - Ini untuk } \\
\text { melepaskan konfigurasi } \\
\text { jaringan Windows. Lalu Ketik } \\
\text { ipconfig/renew - Ini untuk } \\
\text { memperbarui setting IP } \\
\text { Windows, jadi komputer ini } \\
\text { akan mendapatkan informasi } \\
\text { baru dari modem atau router } \\
\text { yang ada.AND Ganti setingan } \\
\text { IP } \text { dari staticke } \\
\text { dynamicTHENIP address } \\
\text { Conflict }\end{array}$ \\
\hline 5. & $\begin{array}{lr}\text { IF Status } & \text { LAN } \\
\text { disableANDSlot } & \text { LAN } \\
\text { dalam } & \text { keadaan } \\
\text { rusakANDHub/Switchdal } \\
\text { am keadaan panas } \\
\text { THEN DHU(destination } \\
\text { host unreachable) }\end{array}$ & $\begin{array}{l}\text { IFKembalikan staus LAN ke } \\
\text { enable AND Hubungkan kabel } \\
\text { jaringan tersebut dengan baik } \\
\text { pada posisinya, jika tidak bisa } \\
\text { coba gunakan } \\
\text { Komputer/Laptop lain, tapi jika } \\
\text { Komputer/Laptop tersebut bisa } \\
\text { terhubung berarti laptop yang } \\
\text { tadi diganti Slot LAN-nya } \\
\text { rusak maka perlu di ganti baru. } \\
\text { ANDMatikan terlebih dahulu } \\
\text { HUB/Switch dan diamkan } \\
\text { selama 4-5 menit lalau } \\
\text { hidupkan kembaliTHEN DHU } \\
\text { (destination host unreachable) }\end{array}$ \\
\hline 6. & $\begin{array}{l}\text { IF Pemakaian bandwidth } \\
\text { sudahpenuhANDFirewall } \\
\text { dalam keadaan hidup } \\
\text { AND Koneksi internet } \\
\text { Rendah THEN RTO } \\
\text { (request time out) }\end{array}$ & $\begin{array}{lr}\text { IFPerhatikan } & \text { setiap } \\
\text { penggunaan bandwidth secara } \\
\text { rutinAND Matikan Windows } \\
\text { FirewallAND Pastikan tidak } \\
\text { terlalu jauh jarak anda } \\
\text { menggunakan jaringan, letakan }\end{array}$ \\
\hline
\end{tabular}

\begin{tabular}{|l|l|}
\hline & $\begin{array}{l}\text { router di dalam ruangan hal ini } \\
\text { dapat meminimalisir jarak dari } \\
\text { router untuk membagi jaringan } \\
\text { dengan pengguna lain. batasi } \\
\text { pengguna jaringanTHEN } \\
\text { RTO(request time out) }\end{array}$ \\
\hline
\end{tabular}

Tabel 2. Rule Sistem Pakar

\begin{tabular}{|c|c|c|c|}
\hline No & IF & THEN & Keterangan \\
\hline 1. & $\begin{array}{l}\text { G1 = Nama Wifi } \\
\text { menghilang } \\
\text { G2 = Password } \\
\text { berubah } \\
\text { G3 = Nama Wifi } \\
\text { kembali ke setingan } \\
\text { Awal }\end{array}$ & P1 & Router default \\
\hline 2. & $\begin{array}{l}\text { G4 = Hotspot } \\
\text { tidakmenggunakan } \\
\text { DHCPatau IP secara } \\
\text { otomatis } \\
\text { G5 = Loadig page } \\
\text { lambat saat } \\
\text { browsing } \\
\text { G6 = Terlalu banyak } \\
\text { Pengguna }\end{array}$ & $\mathrm{P} 2$ & $\begin{array}{l}\text { Internet limited } \\
\text { acces }\end{array}$ \\
\hline 3. & $\begin{array}{l}\text { G7 = Indikator pada } \\
\text { LAN Card tidak } \\
\text { menyala } \\
\text { G8 = Indikator } \\
H U B / S w i c h \text { tidak } \\
\text { menyala } \\
\text { G9 = Kabel tidak } \\
\text { terpasang dengan } \\
\text { baik/rusak }\end{array}$ & P3 & $\begin{array}{l}\text { Network cable is } \\
\text { Unplugged }\end{array}$ \\
\hline 4. & $\begin{array}{l}\text { G10 = } r \text { Simbol } \\
\text { Wifitanda } \\
\text { kuning } \\
\text { G11 = Terdapat IP } \\
\text { yang sama } \\
\text { dibeberapa } \\
\text { pengguna } \\
\text { G12 } \\
\text { menggunakan IP } \\
\text { address yang } \\
\text { Statis }\end{array}$ & P4 & $\begin{array}{ll}\text { IP } & \text { address } \\
\text { conflict } & \end{array}$ \\
\hline 5. & $\begin{array}{l}\text { G13 = Status LAN } \\
\text { disable } \\
\text { G14 = Slot LAN } \\
\text { dalam keadaan rusak } \\
\text { G15 = Hub/Switch } \\
\text { dalamkeadaan } \\
\text { Panas }\end{array}$ & P5 & $\begin{array}{l}\text { DHU (destination } \\
\text { host unreachable) }\end{array}$ \\
\hline 6. & $\begin{array}{l}\text { G16 }= \\
\text { Pemakaianbandwidt } \\
\text { hsudah } \\
\text { penuh } \\
\begin{array}{l}\text { G17 = } \\
\text { dalam } \\
\text { hidup }\end{array}\end{array}$ & P6 & $\begin{array}{l}\text { RTO(request time } \\
\text { out })\end{array}$ \\
\hline
\end{tabular}


E. Implementasi Sistem

1. Halaman Home

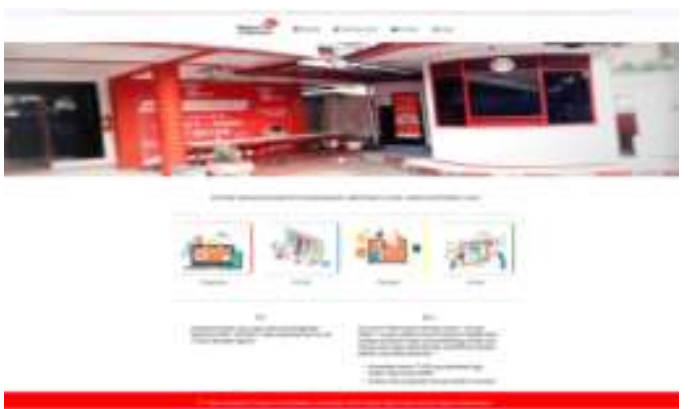

Gambar 4. Halaman Home

\section{Halaman Profile}

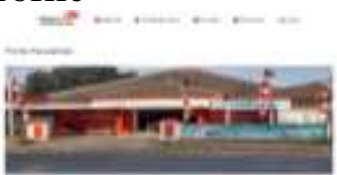

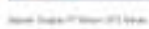

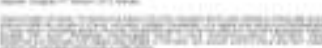

SWA

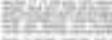

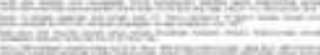

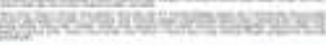

Gambar 5. Profile

\section{Halaman Panduan}

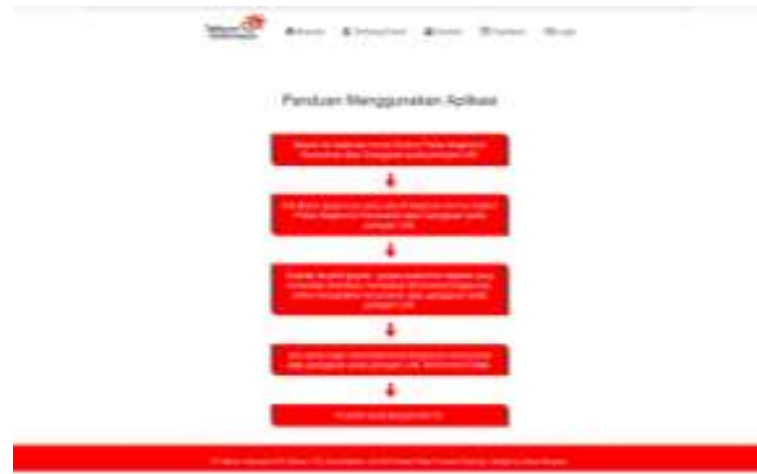

Gambar 6. Halaman Panduan

\section{Halaman Artikel}

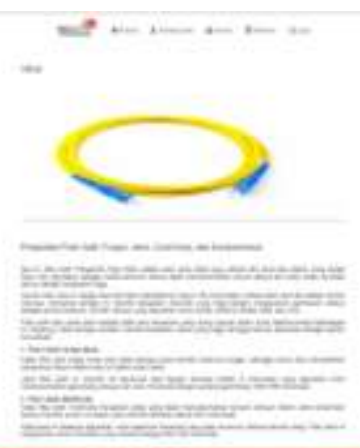

Gambar 7. Halaman Artikel

\section{Halaman Registrasi}

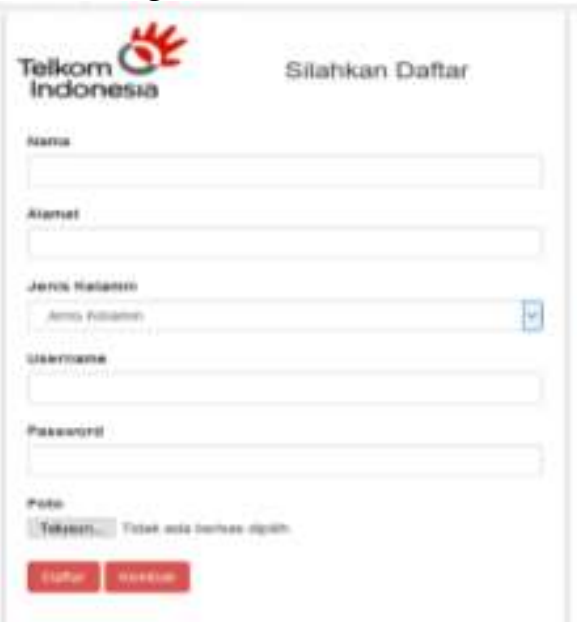

Gambar 8. Halaman Registrasi

\section{Halaman Login}

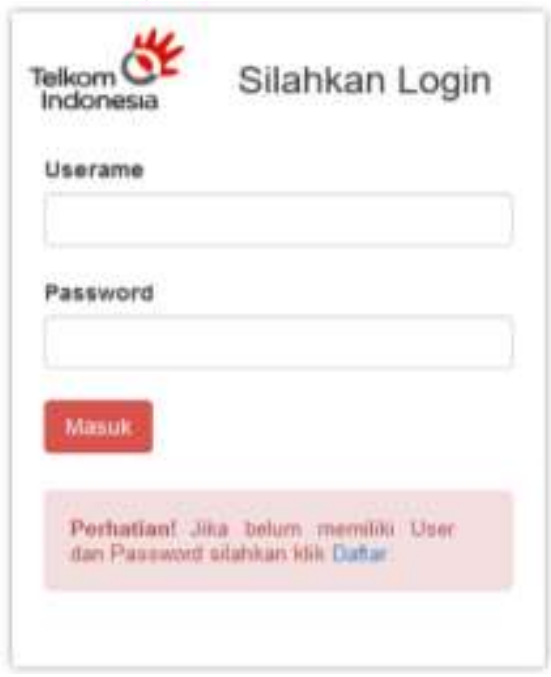

Gambar 9. Halaman Login

\section{Halaman Diagnosis}

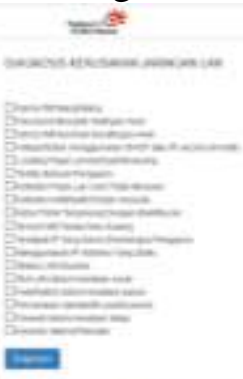

Gambar 10. Halaman Diagnosis 


\section{Halaman Dashboard}

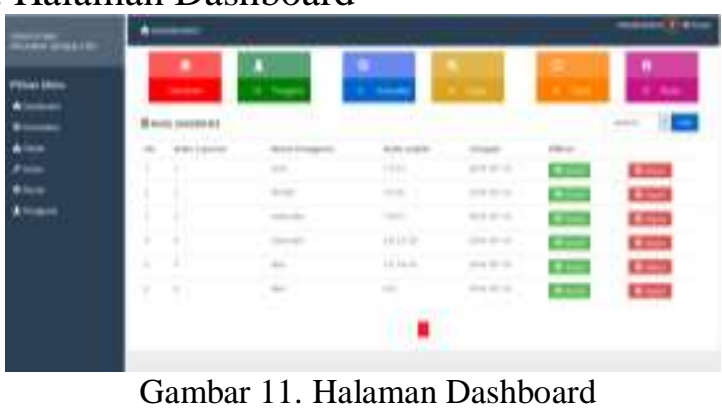

9. Halaman Kerusakan

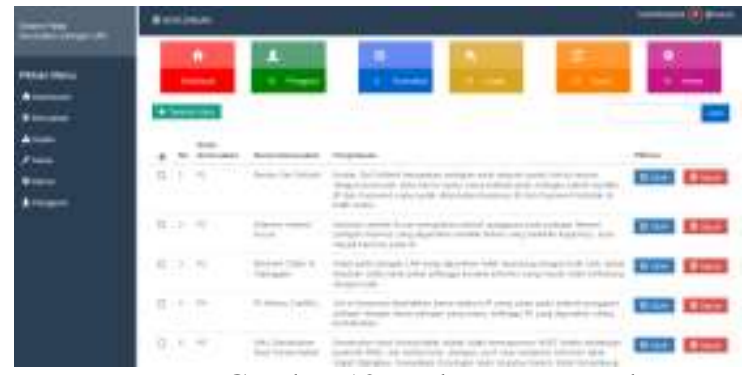

Gambar 12. Halaman Kerusakan

\section{Form Tambah Data Kerusakan}

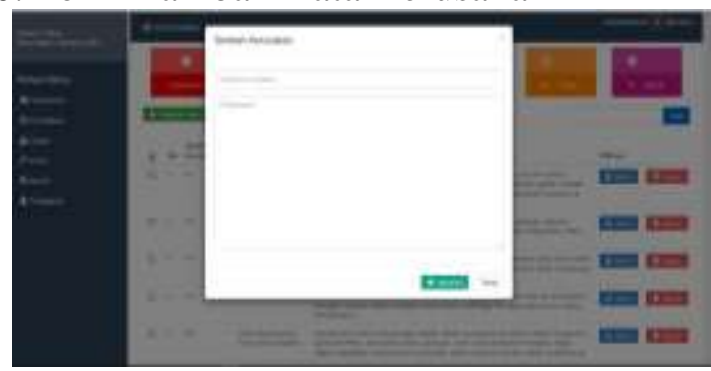

Gambar 13. Form Tambah Data Kerusakan

\section{Halaman Gejala}

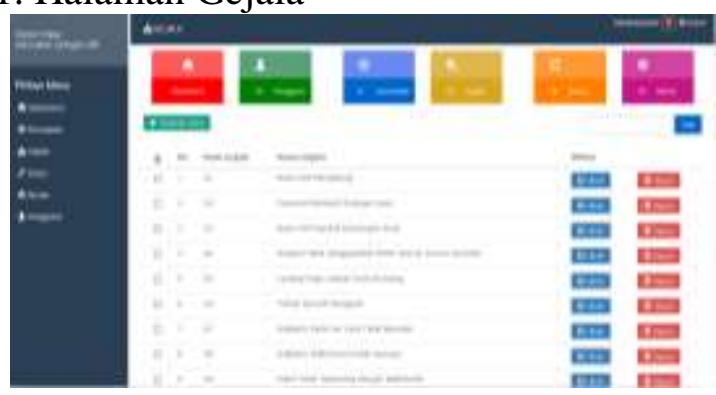

Gambar 14. Halaman Gejala

\section{FormTambah Data Gejala}

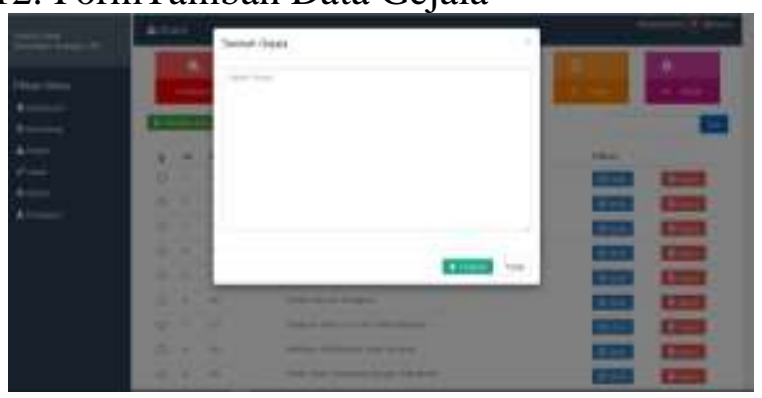

Gambar 15. Form Tambah Data Gejala

13. Halaman Solusi

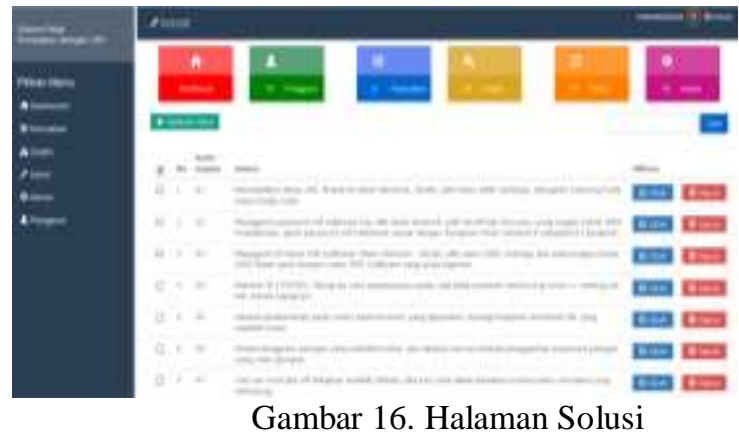

14. Form Tambah DataSolusi

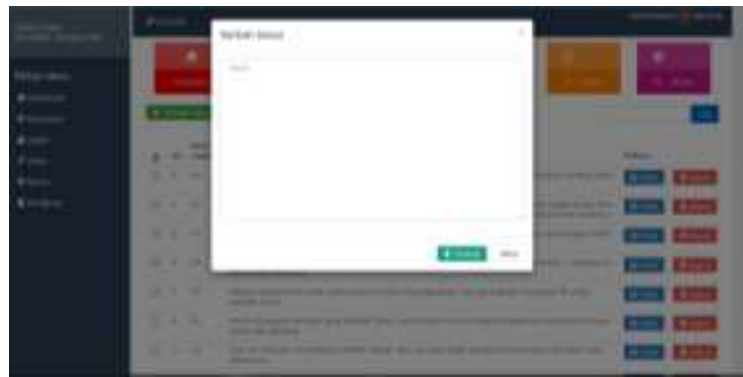

Gambar 17. Form Tambah Data Solusi

\section{Halaman Aturan}

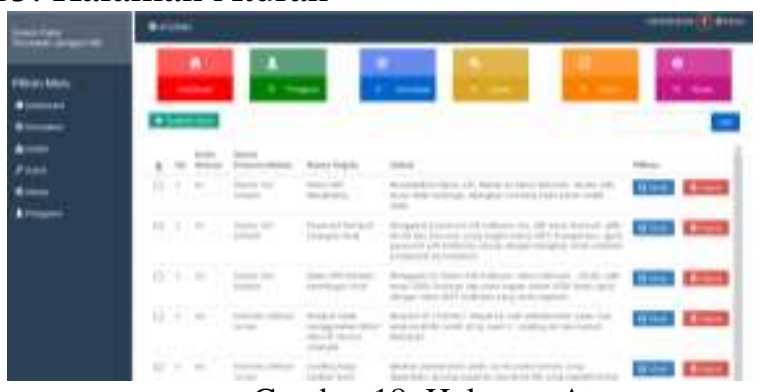

Gambar 18. Halaman Aturan 


\section{FormTambah Data Aturan}

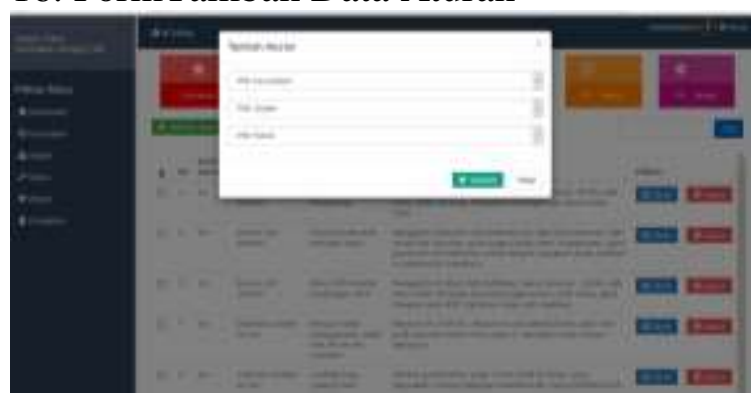

Gambar 19. Tambah Data Aturan

\section{Halaman Pengguna}

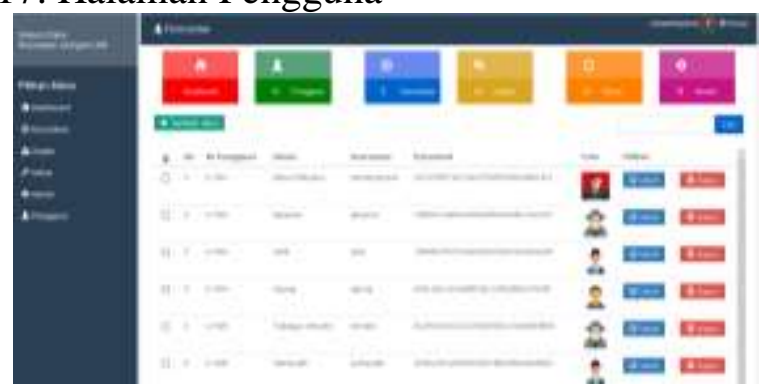

Gambar 20. Halaman Pengguna

\section{Form Tambah Data Pengguna}

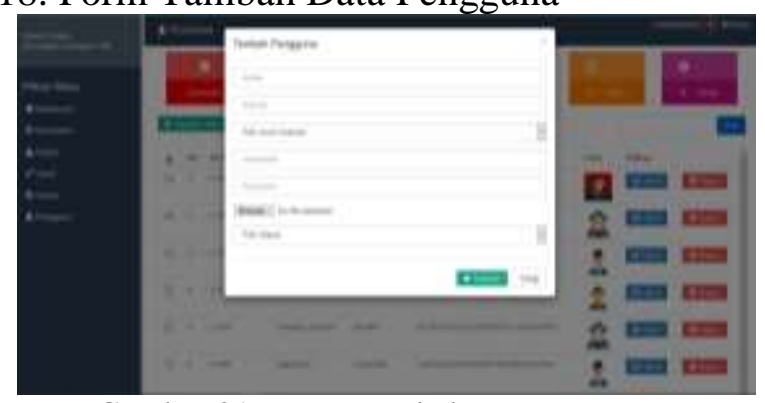

Gambar 21. Form Tambah Data Pengguna

\section{KESIMPULAN}

Berdasarkan hasil pembahasan teori pada perancangan sistem pakar diagnosis kerusakan jaringan Local Area Network (LAN) dapat disimpulkan sebagai berikut :

Terealisasinya perancangan sistem pakar untuk memecahkan permasalahan dan memberikan informasi serta solusi penanganan tentang kerusakan jaringan Local Area Network (LAN).

Sistem pakar kerusakanjaringan Local Area Network (LAN) sudah memberikan solusi secara cepat dan tepat bagi para pengguna jaringan LAN ketika jaringan mengalami kerusakan atau gangguan.

Sistem pakar ini menggunakan metode forward chaining dan dirancang sedemikian rupa agar mudah dipahami dan dimengerti serta perancangan sistem pakar ini sudah memberikan pemahaman bagi para pengguna jaringan tentang kerusakan atau gangguan pada jaringan Local Area Network (LAN).

\section{REFERENSI}

[1] Fatta, Hanif. (2007). Analsis dan Perancangan Sistem Informasi. Yogyakarta:Andi.

[2] Jogiyanto, HM. (2005). Analisis dan Desain Sistem Informasi Yogyakarta : Andi.

[3] J. Hutahaen. (2015). Konsep Sistem Informasi, Yogyakarta Deepublish

[4] Kadir, Abdul.(2003). Pengenalan Sistem Informasi. Yogyakarta Andi Offset.

[5] Maniah. \& Dini Hamidin. (2017). Analisis dan Perancangan Sistem Informasi Pembahasan Secara Praktis Dengan Contoh Kasus, Yogayakarta : Deepublish

[6] Mulyadi. (2016). Sistem Informasi Akuntansi. Jakarta : Salemba Empat

[7] Nurhadi. (2017). Pondasi Pemrograman Website, SurabayaJawa timur : CV.Garuda Mas Sejahtera

[8] Raharjo, Budi. (2011). Membuat database menggunakan mysql. Bandung : Informatika

[9] Sukamto R,A. dan M. Shalahuddin.(2013). Rekayasa Perangkat Lunak. Bandung: Informatika

[10] Sutabri, Tata.(2003). Analisa Sistem Informasi. Yogyakarta Andi Offset.

[11] Sutabri, Tata.(2004). Analisa Sistem Informasi. Yogyakarta : Andi Offset.

[12] Suryana, A. (2003). Kewirausahaan. Jakarta : Salemba Empat.

[13] Sugiyono. (2013). Metodelogi Penelitian Kuantitatif, Kualitatif dan R\&D. Bandung : Alfabeta 